\title{
Alexandre Dumas, en société avec Claude Schopp, Le Salut de l'Empire. Hector de Sainte-Hermine
}

\section{Lise Sabourin}

\section{(2) OpenEdition}

1 Journals

\section{Édition électronique}

URL : http://journals.openedition.org/studifrancesi/8298

DOI : 10.4000/studifrancesi.8298

ISSN : 2427-5856

Éditeur

Rosenberg \& Sellier

\section{Édition imprimée}

Date de publication : 1 mai 2009

Pagination : 191-192

ISSN : 0039-2944

\section{Référence électronique}

Lise Sabourin, «Alexandre Dumas, en société avec Claude Schopp, Le Salut de l'Empire. Hector de Sainte-Hermine », Studi Francesi [En ligne], 157 (LIII | I) | 2009, mis en ligne le 30 novembre 2015, consulté le 07 janvier 2021. URL : http://journals.openedition.org/studifrancesi/8298; DOI : https:// doi.org/ERREUR PDO dans /localdata/www-bin/Core/Core/Db/Db.class.php L.34 : SQLSTATE[HY000] [2006] MySQL server has gone away

Ce document a été généré automatiquement le 7 janvier 2021.

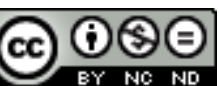

Studi Francesi è distribuita con Licenza Creative Commons Attribuzione - Non commerciale - Non opere derivate 4.0 Internazionale. 


\title{
Alexandre Dumas, en société avec Claude Schopp, Le Salut de l'Empire. Hector de Sainte-Hermine
}

\author{
Lise Sabourin
}

\section{RÉFÉRENCE}

ALEXANDRE DUMAS, en société avec Claude SCHOPP, Le Salut de l'Empire. Hector de Sainte-

Hermine, Paris, Phébus, 2008, pp. 732.

1 Après Le Chevalier de Sainte-Hermine (ibid., 2005) que Claude Schopp avait ressuscité des feuilletons du «Moniteur universel» de 1869 , voici qu'en nègre posthume - après Maquet et sa «botte de plans» - le grand spécialiste dumasien nous offre la suite de cet ultime roman. Il a osé lever l'interdit lancé aux critiques, c'est-à-dire prendre le relais de l'écrivain, d'après le plan laissé par Dumas, quelques feuilles manuscrites trouvées aux archives de Prague et trois chapitres inédits miraculeusement ressurgis du commerce des autographes pour confirmer ses déductions. L'accomplissement du «programme héroïque» d'Hector de Sainte-Hermine lui étant ainsi assuré, Claude Schopp saisit l'occasion de la publication précédente pour faire paraître le rêve de ses longues années d'écriture en communion avec son auteur favori.

2 Nous laisserons au lecteur le goût de découvrir comment «l'étoile polaire» qui a dirigé Claude Schopp - la prédiction faite à Claire de Sourdis dans le volume antérieur qu'elle serait «quatorze ans veuve d'un vivant, puis épouse d'un mort» - se réalise au rythme d'aventures effrénées de Capri à Vienne, des terres indiennes à la Russie, d'Elbe à Waterloo.

3 Mais la réussite du pari est totale: alacrité du style, efficacité des chapitres (Schopp a respecté le découpage virtuel en feuilletons de 17000 signes), personnalisation du récit au fil des expériences vitales des protagonistes, mais aussi représentation du mouvement de l'Histoire (le collaborateur «en société avec Dumas» s'est nourri 
exclusivement de ses sources d'époque, notamment l'Histoire de Napoléon et de la grande Armée pendant l'année 1812 du comte de Ségur). 